\title{
GAYA HIDUP URBAN DALAM HANACO
}

Urban's Lifestyles on Hanaco

\section{Resti Nurfaidah}

Balai Bahasa Jawa Barat

pos-el: sineneng1973@gmail.com

\section{Naskah Diterima 30 Juli 2018-Direvisi Akhir 3 Desember 2018-Disetujui 4 Desember 2018 doi.org/10.26499/jentera.v7i2.892}

\begin{abstract}
Abstrak: Makalah ini berjudul "Ekstasi Gaya Hidup Urban dalam Hanaco". Makalah ini memaparkan kondisi manusia urban yang terjebak dalam kungkungan budaya massa. Pembahasan dalam makalah ini dibatasi pada tiga hal berikut, yaitu perkawinan dan parenting, masalah dan penyelesaian masalah, serta hubungan antarmanusia. Tujuan dari penulisan makalah ini adalah mendapatkan jawaban atas ketiga masalah tadi. Pembahasan tersebut menggunakan metode penelitian kualitatif dengan pendekatan cultural studies pada pengaruh budaya massa, terutama di kalangan manusia urban yang terdapat pada data penelitian berupa novel-novel karya Indah Hanaco, yaitu (1) Black Angel,(2) The Curse of Beauty: Metrolifestyle Sales Promotion Girl, (3) Le Masques, (4) My Better Half, (5) You Had Me at "Hello", (6) Heartling, (7) Out of the Blue, (8) Delicious Married, (9) The Passionate Married,(10) Fixing A Broken Heart, dan (11) Millionaire's Heart.Hasil peneletian menunjukkan adanya pergeseran pandangan manusia urban terhadap perkawinan, konsep parenting, masalah dan penanganan masalah, serta hubungan antarmanusia.
\end{abstract}

Kata-kata kunci: urban, budaya, Hanaco

Abstracts: "The Ecstasy of Urban Lifestyle in Hanaco" described human in urban lifestyle who was being trapped in its cultural values. It was focused onto the following three points: marriage and parenting, problems and their solvings, and interhuman relationships. This paper aims to answer these three problems: how urban people ran their marriage and parenting, how they ran their prolems and found solutions, and how they do interhuman relationships. It was a qualitative research by cultural studies view through the influence of culture, especially among urban human, on such novels of Indah Hanaco : (1) Black Angel,(2) The Curse of Beauty: Metrolifestyle Sales Promotion Girl, (3) Le Masques, (4) My Better Half, (5) You Had Me at "Hello", (6) Heartling, (7) Out of the Blue, (8) Delicious Married, (9) The Passionate Married, (10) Fixing A Broken Heart, dan (11) Millionaire's Heart.The results were the shift marriage and parenting, many problems and the way they solved them, and interhuman relationships.

Keywords: urban, culture, and Hanaco

How to cite: Nurfaidah, Resti. (2018). Gaya Hidup Urban dalam Hanaco. Jentera: Jurnal Kajian Sastra, 7 (2), 215-233. (https://doi.org/10.26499/jentera.v7i2.892).

\section{PENDAHULUAN}

Purwantini (2010: 544-545) menyampaikan bahwa tempat hidup masyarakat secara garis besar terbagi atas dua bagian, yaitu wilayah pedesaan (rural) dan wilayah perkotaan (urban) yang memiliki karakter khas tersendiri. Takwin (2006: 129) 
menyebut kota sebagai tempat permukiman yang tetap dengan derajat kompleksitas yang tinggiMaranoes (2007 dalam www.liputan6.com) menyampaikan bahwa kota menjadi magnet untuk hidup, terutama terkaiturbanisasi, terbukti dengan banyaknya para pemburu nasib saat arus balik Lebaran, misalnya, yang tidak kembali ke desa, tetapi menetap di kota. Jamaludin (2015: 24--25), menyampaikan bahwa bagi orang desa, kota dianggap sebagai tempat yang berbahaya, harus waspada, banyak pengetahuan, dan muslihatnya. Namun, kota juga merupakan pusat kekuasaan, kekayaan, sekaligus pengetahuan. Wajah pedesaan pada umumnya identik dengan kehidupan yang serbaerat antaranggota keluarga maupun warga. Lahan pencarian pada umumnya sebagai petani, peternak, pekebun, atau sederet jenis pekerjaan yang bergantung pada kekuatan alam. Sementara itu, Soerjono (2002: 156-157) memberikan ciri-ciri khas kehidupan di perkotaan sebagai berikut: (1) Kehidupan keagamaan masyarakat kota tidak sekhusuk dan sekental seperti kehidupan keagamaan masyarakat pedesaan; (2) orang-orang kota pada umumnya dapat mengurus dirinya sendiri tanpa tergantung pada orang lain; (3) pembagian kerja antara warga kota lebih tegas dan punya batas-batas nyata; (4) memiliki pola pikir rasional; (5) perubahanperubahan sosial lebih kentara karena sifat kota yang lebih terbuka. Purwantini (2010: 545) juga menambahkan bahwa masyarakat kota merupakan multietnis dengan keragaman latar budaya, tetapi adanya pembakuan budaya aristokrat pada kalangan menengah dan kaum elit.

Makalah ini akan menyoroti situasi dan kondisi masyarakat yang hidup dalam wilayah urban dan dijejali dengan nilai-nilai urban sebagaimana tergambar beberapa novel Indah Hanaco yang dijadikan sebagai sampel data, seperti Black Angel, The Curse of Beauty: Metrolifestyle Sales Promotion Girl, Le Masques, My Better Half, You Had Me at "Hello", Heartling, Out of the Blue, Delicious Married, The Passionate Married, Fixing A Broken Heart, danMillionaire's Heart. Hanaco merupakan salah seorang novelis kontemporer yang menyoroti kehidupan manusia urban, terutama dari kalangan menengah, dengan segenap kompleksitasnya. Penelitian dalam makalah ini dibatasi pada gambaran manusia urban dalam menghadapi nilai-nilai urban itu sendiri, dampak dari nilai-nilai urban yang dikaitkan dengan gaya hidup dalam kebudayaan massa terhadap kehidupannya sendiri dan lingkungan di sekitarnya, serta solusi apa yang disarankan oleh Hanaco untuk mengatasi dampak tersebut. Tujuan penulisan 
makalah ini tidak lain untuk memberikan sumbangan pada khazanah sastra, terutama sastra kontemporer, berkaitan dengan sikap dan gambaran manusia urban, budaya urban, dan budaya massa, dengan segenap kompleksitasnya yang tergambarkan dalam serangkaian karya sastra.

Penelitian tentang budaya urban cukup banyak dilakukan, di antaranya (Jabrohim, 2010: 517-520) memandang pemusatan gaya hidup urban sebagai orientasi perut pada sembilan bidang kehidupan di Yogyakarta. Kesembilan bagian tadi pada mulanya berjalan harmonis. Namun, seiring perkembangan sosial budaya yang tidak terduga, wajah Yogyakarta pun berubah pula dengan cepat. Jabrohim (2010: 520) Yogya kini tidak lagi sebagai kota pelajar yang murni, melainkan beralif fungsi sebagai kota ekonomi dan pasar konsumsi. Perubahan tersebut dapat terlihat dengan kasat mata, antara lain, adanya pertokoan di area Keraton; serta orientasi konsumtif dan komersialisasi pada institusi pendidikan, lembaga keagamaan, peringatan hari besar, media jurnalistik, dan perumahan.

\begin{abstract}
Mustikasari (2018: x) dalam skripsi berjudul "Perilaku Gangguan Identitas Dissosiatif (GID) Tokoh Fleur Radella dalam Novel Les Masques Karya Indah Hanaco: Sebuah Pendekatan Struktural dan Psikoanalisis" membahas tentang kepribadian ganda pada tokoh utama bernama Fleur. Child abuse yang dilakukan oleh nenek (Martini) kepada Fleur sejak ia kecil sampai remaja, berikut sederet perisitiwa pelecehan seksual yang dilakukan oleh beberapa laki-laki di lingkungan sekitar Fleur melahirkan beberapa tokoh alter ego. Akibat perlakuan buruk tersebut, Fleur mengalami depersonalisasi, derealisasi, mengalami amnesia disosiatif, kecemasan dan depresi, perubahan identitas tanpa disadari, serta sakit kepala. Setiap tokoh, baik tokoh Fleur Radella maupun alter-alter ego yang muncul sangat kuat sehingga memiliki struktur kepribadiannya sendiri di setiap momen. Alter ego akan muncul pada saat hasrat muncul. Hasrat yang muncul (id), pertimbangan dari hati nurani (superego), dan apa yang akhirnya dilakukan (ego) oleh setiap tokoh berbeda-beda.
\end{abstract}

Kajian lain, dilakukan oleh Nurfaidah (2016: 1-15) dalam makalah berjudul "Dampak Disfungsi Keluarga terhadap Mitos dan Kecantikan dalam Novel The Curse of Beauty: Metrolifestyle Sales Promotion Girl" yang menyampaikan bahwa masalah perkawinan orang tua, tidak hanya berdampak pada hubungan keluarga, melainkan pada cara pandang korban perceraian orang tua terhadap kecantikan. Pada awalnya, tokoh Lea memandang bahwa kecantikan sang ibu hanya dipersembahkan untuk suaminya. Namun, masalah pelik di antara kedua orang tuanya tanpa diketahui gadis itu tiba-tiba sampai pada tahapan perceraian. Lea mengalami shock. Kemudian ia berubah haluan dan menjual kecantikan yang ia miliki dengan topeng sebagai seorang SPG. Dari ketiga kajian tadi dapat diambil kesimpulan bahwa nilai-nilai urban memiliki kecenderungan pada pengutamaan aspek materialistis. Hubungan antarsesama dipandang berdasarkan 
unsur kepentingan pribadi, serta penyelesaian masalah dengan tanpa pola pikir panjang. Makalah ini lebih menyoroti pada aspek perkawinan, parenting, masalah dan penyelesaian masalah pada beberapa novel karya Indah Hanaco.

\section{LANDASAN TEORI}

Wilayah urban dengan segenap keragaman dan keterbukaan menumbuhkan budaya massa. Damono (1997: 48), budaya massa kerapkali dianggap sebagai penggeser budaya daerah. Damono (1997: 48) juga menyampaikan bahwa kebudayaan di mana pun selalu mengalami perubahan atau pengembangan, sebagai bukti persinggungan satu kebudayaan dengan kebudayaan lain. Ia mengatakan bahwa tidak mungkin jika kebudayaan berkembang dengan sendirinya . Manusia, terutama di urban, juga mengalami perubahan, baik pada latar kebudayaan daerah yang diusungnya sebagai pendatang maupun budaya yang kini ia geluti yang lebih cenderung bergeser ke budaya Barat, sebagai bukti bahwa ia mampu bergerak dengan cepat. Damono (1997: 49—50) menyaampaikan bahwa hadirnya kebudayaan massa tersebut justru mengundang kekhawatiran banyak pihak, di antaranya: (1) kebudayaan massa diproduksi secara besar-besaran dengan perhitungan dagang belaka; (2) kebudayaan massa dianggap dapat merusak kebudayaan elit dengan cara meminjam, mencuri, atau meminjamnya - dalam kondisi yang lebih ekstrem, Damono mengatakan bahwa kebudayaan massa kerapkali menyedot potensi yang ada di dalam kebudayaan elit; (3) kebudayaan massa menanamkan pengaruh yang sangat buruk terhadap khalayak karena ia tidak dapat menghindari tiga ciri khas kebudayaan massa (sex, crime, and violence), serta (4) penyebarluasan kebudayaan massa dianggap tidak hanya memerosotkan atau mengurangi nilai kebudayaan elit itu sendiri, tetapi juga menciptakan khalayak yang pasif yang sangat tanggap terhadap berbagai teknik godaan dan bujukan (iklan) sehingga membuat peluang bagi munculnya totalitarianism. Merujuk pada konsep yang digoreskan Damono (1997: 50) pada butir keempat tersebut, kuatnya pengaruh kebudayaan massa yang merebak pada segala lapisan masyarakat, dari si miskin sampai si kaya, menunjukkan bahwa kebudayaan massa telah menguasai bangsa-bangsa di dunia. Masyarakat diseragamkan oleh kebudayaan massa. Satu saran Damono (1997: 48 -51) dalam menghadapi kebudayaan massa adalah tidak bersikap pasif terhadap perkembangan kebudayaan itu. Manusia harus bersikap proaktif agar dapat mengembangkan kebudayaan sendiri. 
Kuntowijoyo (1997: 88) menyampaikan bahwa budaya massa terjadi akibat massafikasi, yang terjadi karena munculnya industrialisasi dan komersialisasi dalam kebudayaan. Kuntowijoyo menyampaikan ciri-ciri budaya massa berikut, yaitu (1) objektivasi, (2) alienasi, dan (3) pembodohan. Objektivasi terjadi jika pemilik hanya menjadi objek yang tidak dapat berperanan apa pun dalam pembentukan budaya-yang sudah berwujud menjadi produk budaya jadi. Alienasi yakni kondisi pemilik budaya massa yang terasing dari/dalam kenyataan hidup. Sementara itu, pembodohan terjadi waktu terbuang percuma dengan tidak menghasilkan pengalaman baru. Kuntowijoyo menyampaikan pula kiat untuk mengatasi massafikasi,yaitu melalui privatisasi dan spiritualitas. Privatisasi merupakan kiat untuk menekankan segala hal secara pribadi agar tidak sama dengan yang lain. Spiritualitas merupakan upaya untuk mengadopsi budaya spiritual, baik pribadi maupun kelompok. Dalam hal ini, Kuntowijoyo (1997: 56) tidak menafikan adanya pelekatan simbol kealiman, misalnya konsep keagamaan yang kini muncul di kalangan masyarakat urban. Hal itu dapat diartikan sebagai reduksi terhadap dunia keagamaan, selama tidak melanggar dasar akidah dan undang-undang.

Ibrahim (1997: 14) mengatakan bahwa dalam kebudayaan massa terdapat kecenderungan untuk menjadikan gaya hidup sebagai komoditas dan, sebaliknya, komoditas sebagai gaya hidup melalui pembokangkaran secara radikal. Ibrahim (1997: 14) menyampaikan pula bahwa masyarakat modern kini hidup dalam kenikmatan semu, kebahagiaan sarat ilusi, keindahan sarat halusinasi, serta daya tarik pseudo-rasional yang terendapkan dalam pesan budaya sehari-hari yang mencabik-cabik aura simbolis dalam sebuah panggung ekstasi. Ibrahim (1997: 14) menggabarkan kesemuan tersebut sebagai pil cinta yang membius manusia ke dalam kondisi psikologis yang telanjang. Ibrahim (1997: 15) mengibaratkan bahwa di atas panggung tersebut dipertunjukkan pemujaan akan gaya hidup yang luar biasa, tetapi tanpa di sadari terdapat jurang lebar ketidaksadaran yang disadari dan kesadaran yang tidak disadari. Di antara kedua hal itu, massa yang merupakan manusia modern dijejali dan dibius dengan serangkaian nilai yang berasal dari berbagai penjuru dunia. Akibatnya muncullah dampak ekstasi gaya hidup yang membutakan mata dan hati dalam kehidupan manusia modern, yang mengarah pada konsep khayali-meskipun dikonstruksi seolah-olah semua serbarealitas. Ibrahim (1997: 21) mengaitkan pula standardisasi produk yang melalui tangan media massa dan industri budaya menyebabkan terjadinya keseragaman cita rasa 
yang mengarah pada komersialisasi. Produk budaya yang muncul lalu gemar menyebar budaya "pop" yang tidak pernah terhenti produksinya di kalangan massa, bahkan dalam bentuk yang dikonstruksi sesuai dengan kondisi masyarakat sendiri. Ibrahim memberikan beberapa ciri utama kebudayaan tersebut, yaitu orisinalitas yang spontan, eksistensinya yang berlangsung terus dalam kehidupan sosial dengan pernik yang beragam, seperti bahasa, busana, musik, atau tata cara.

\section{METODE PENELITIAN}

Penelitian ini merupakan kualitatif berbasis analisis deskriptif. sumber data yang digunakan dalam penelitian ini adalah beberapa novel karya Indah Hanaco berikut, yaitu Black Angel, The Curse of Beauty: Metrolifestyle Sales Promotion Girl, Le Masques, My Better Half, You Had Me at "Hello", Heartling, Out of the Blue, Delicious Married, The Passionate Married, Fixing A Broken Heart, dan Millionaire's Heart. Data yang digunakan adalah situasi dan kondisi masyarakat yang hidup dalam wilayah urban dan dijejali dengan nilai-nilai urban. Situasi dan kondisi tersebut diteliti dengan konsep budaya massa sebagai dampak hadirnya wilayah urban dan kompleksitas yang ditimbulkan di wilayah itu. Teknik pengumpulan data dilakukan dalam beberapa tahapan, pengumpulan sumber data berupa novel karya Indah Hanaco, serta pembacaan cermat pada sumber data, pengamatan cermat pada data yang berkaitan dengan situasi dan kondisi masyarakat yang hidup dalam wilayah urban dan dijejali dengan nilai-nilai urban. Data yang terkumpul lalu 1) dianalisis berdasarkan konsep yang digunakan; 2) dibagi ke dalam empat segmen, yaitu perkawinan dalam Hanaco, parenting dalam Hanaco, masalah dan penyelesaian masalah, serta hubungan antarmanusia; dan 3) hasil analisis dituangkan dalam bentuk makalah ilmiah.

\section{PEMBAHASAN}

Pembahasan dibagi menjadi beberapa bagian, yaitu perkawinan dalam Hanaco, dan parentingdalam Hanaco,masalah dan penyelesaian masalah, serta hubungan antarsesama. Sementara itu, judul novel akan disingkat berikut: Black Angel (BA), The Curse of Beauty: Metrolifestyle Sales Promotion Girl (CBMSP), Le Masques (LM), My Better Half(MBH), You Had Me at "Hello" (YHMH), Heartling (HG), Out of the Blue (OB), Delicious Married (DM), The Passionate Married (PM), Fixing A Broken Hear (FBH), dan Millionaire's Heart $(\mathrm{MH})$, untuk memudahkan dalam proses pembahasan. 


\subsection{Perkawinan dalam Hanaco}

Perkawinan bukan hal mudah. Hal itu didukung oleh pandangan Marbun, dalam /www.kompasiana.com diunduh 21 November 2018, yang menyampaikan bahwa perkawinan yang ideal adalah perkawinan yang dilandasi dengan kesiapan dalam hal usia dan fisik, mental, dan materi.Dengan demikian, pasangan suami-istri mampu menangani masalah dan halangan dalam pernikahan. Namun, dalam kehidupan modern, perkawinan pun menjadi sebuah komoditas dengan berbagai rekayasa yang cukup hebat. Hanaco menggambarkan hal itu dalam novel FBH, YHMH, BA, HG, PM, dan CBMSP. FBH menunjukkan sepasang suami-istri, Ferdy-Verna, yang memiliki kesamaan minat dalam penyimpangan seksual. Kedua suami-istri itu sama-sama mengalami titik jenuh dalam perjalanan bahtera mereka. Namun, mereka memilih untuk menciptakan nuansa yang berbeda sebagai solusi atas kejenuhan tersebut. Dengan meminta bantuan tokoh Yenny, yang dianggap mumpuni dalam menilai seseorang, pasangan tersebut mengadakan sayembara pemilihan staf untuk perusahaan. Tanpa diketahui oleh tokoh Yenny, pemilihan tersebut ternyata dilakukan untuk memilih pasangan threesome bagi pasutri tersebut. Hal itu terungkap dalam kutipan tuturan tokoh Yenny, berikut.

"Menurut Tante Verna, menikah puluhan tahun itu butuh variasi supaya nggak sampai bosan. Yang paling berpengaruh itu... hmmm... seputar urusan ranjang. Dia bilang, selama bertahuntahun dia dan suaminya sudah melakukan berbagai... cara. Tujuannya, untuk membuat hidup tetap bergairah. Mulai dari bertukar pasangan hingga... hingga..." Yenny kesulitan menuntaskan kalimatnya. Pipi Brisha terasa membeku. (Hanaco, FBH, 2017:150)

Selanjutnya, tokoh Yenny menyampaikan bahwa tokoh Rifat yang ia wawancarai merupakan orang yang terpilih sebagai obat penyegar atas kejenuhan yang menyampaikan pasangan tersebut. Rifat digelari oleh pasangan tersebut sebagai orang yang dibutuhkan untuk membuat pernikahan tetap bergairah (Hanaco, FBH, 2017:142). Sakralitas perkawinan di mata pasangan Ferdy-Verna sudah luntur. Bahkan, mereka membentuk komunitas yang anggotanya sepaham. Kesepahaman itu diwujudkan dengan kerapkalinya mereka mengadakan pesta seks.

Perkawinan lain yang mengalami badai juga dialami oleh orangtua tokoh Austin. Sosok ayah Austin, Teddy, merupakan tipe laki-laki metroseksual narsistis akut, yang selalu harus terlihat spesial di mata publik. Ia gemar akan sanjungan, meskipun untuk itu ia harus menguras keuangan dalam ruamah tangganya hingga benar-benar 
mengalami kehancuran. Astari, istrinya, dan Austin, anak tunggalnya, lalu diabaikannya ketika laki-laki itu tertarik dengan perempuan lain hingga pada suatu hari, ia berusaha kembali pada keluarganya dengan kondisi yang cukup miris. Perempuan yang dulu ia anggap sebagai oase, rupanya hanya ingin menguras harta milik suaminya. Astari yang senantiasa bertahan dengan konsep penghormatan yang tradisional lalu berusaha membuka ruang untuk menerima suaminya kembali. Namun, hal itu, tersandung dengan sikap Austin yang bersikap sebaliknya. Austin rupanya menyimpan dendam kepada ayahnya dan selama mengalami masa-masa sulit bersama ibunya.

Perkawinan yang sulit juga terdapat dalam CBMSP. Atas nama ketidakcocokan, tokoh Mama dan Papa memutuskan untuk berpisah setelah menjalani masa perkawinan selama dua puluh lima tahun. Namun, mereka tidak berusaha untuk saling memberi pengertian satu sama lain atau berusaha untuk memperbaiki, melainkan saling membalas dendam dengan mencari pasangan muda. Hebatnya, semua terjadi tanpa sepengetahuan kedua anak mereka. Tokoh Kimmy tentu saja mengalami syok yang cukup hebat. Perkawinan sudah lepas dari makna hakiki. Penghormatan pada pasangan sudah tidak ada lagi, sebaliknya yang tersisa adalah kebencian satu sama lain.

Mama dan Papa tampak bertukar pandang dengan bermasalah. Lagi-lagi aku mendapati kilatan kebencian di sana. Mama dan Papa benar-benar menanggalkan topengnya hari ini. Mereka tidak berusaha menyembunyikan perasaan sama sekali. Mama dan papa menunjukkan sisi lain dari diri mereka yang sebelumnya tidak pernah tahu. (Hanaco, CBMSP, 2012: 69)

Tokoh Mama dan Papa pada akhirnya memutuskan untuk bercerai dengan tetap meneruskan aksi balas dendam mereka. Dalam HG, potret perkawinan pun hampir sama. Kesibukan duniawi dan hilangnya komunikasi menyebabkan Amara kehilangan ayah dan ibunya. Lalu setelah perceraian tersebut, Amara semakin kehilangan sang ibu karena perempuan itu lebih memilih menyalurkan kekecewaannya pada aktivitas kerja yang cukup ekstrem.

Potret perkawinan bermasalah muncul pula dalam BA, yaitu perkawinan yang dijadikan sebagai topeng penutup aib atau jatidiri tokoh Lazuardi yang sebenarnya. Lazuardi menutupi jatidirnya sebagai seorang penyuka sesama jenis dengan menikahi tokoh Mama. Meskipun telah memiliki dua orang anak, penyimpangan itu tidak dapat diabaikannya, terutama, setelah istrinya memilih sekretaris pribadi laki-laki untuknya, Quinn. Tokoh Mama rupanya tidak pernah mengenali kelainan pada diri suaminya, ia mengira pilihannya itu tepat. Namun, yang terjadi sebaliknya. Pintu Lazuardi semakin 
terkuak dan kesempatan untuk meluapkan dorongan menyimpang itu menjadi tersalurkan tanpa harus dicurigai oleh istri dan anaknya. Ketika pada akhirnya Avril dan Mirza, kedua anak Lazuardi, mendapati penyimpangan tersebut, mereka mengalami syok. Mirza dan Lazuardi akhirnya bunuh diri. Perkawinan bermasalah yang dilandasi penyimpangan seksual terdapat dalam novel PM. Dalam novel tersebut, dihadirkan tokoh Eva sebagai kakak tiri tokoh Gwen. Eva merasa kehadiran Gwen merebut semua kebahagiaan hidupnya. Kekecewaan Eva ditumpahkan dengan meleburkan diri sebagai seorang PSK. Kehadiran Eva di dalam rumah tangga Gwen dan Phillip bertujuan untuk merusak kebahagiaan adik tirinya tersebut. Kegagalan perkawinan kedua orang tua Eva berpengaruh terhadap prilaku anak sulung mereka.

Sakralitas perkawinan dari contoh tadi menunjukkan pergeseran yang cukup radikal. Perkawinan menjadi sarana penyaluran kepentingan pribadi, bahkan menjadi sarana untuk menutupi jatidiri yang sebenarnya. Pada BA merupakan contoh yang paling buruk. Dalam realitas pun demikian adanya, kasus perceraian para selebriti seakan menjadi komoditas yang layak dikonsumsi melalui penyebaran media massa. Atensi massayang cukup signifikan mampu mendongkrak rating dan meninggkatkan keuntungan finansial pada berbagai pihak yang berkepentingan. Perkawinan kini cenderung tidak memiliki batas pagar privasi ketika media dengan leluasa bisa masuk ke setiap inci lahan privasi. Bahkan, untuk adegan intim pun kini dengan mudah tersiar ke ranah publik. Konsep perkawinan tanpa pagar dan tanpa akar pun kini dengan mudah tercerabut dari makna perkawinan yang hakiki.

Satu lagi contoh yang Hanaco berikan melalui karyanya adalah perkawinan atas kepentingan pribadi, yang terdapat dalam novel YHMH. Tokoh Inana terpaksa harus menuruti keinginan papanya untuk mengawini Alistair. Alistair dan kedua orangtuanya sangat terbuka dalam menerima kehadiran Inana. Namun, perkawinan tanpa cinta itu mulai goyah ketika Inana mengetahui bahwa Alistair bersedia menikahinya hanya karena kemiripan fisiknya dengan mantan kekasihnya, Emily. Selain itu, kedua orangtua Alistair rupanya sangat menghendaki pernikahan tersebut untuk mendapatkan pewaris harta karena anak lelaki mereka menderita penyakit yang cukup parah. Inana merasa bahwa perkawinan ini hanya permainan semata demi mendapatkan keinginan bagi pihak yang berkepentingan, Alistair dan kedua orangtuanya. Perkawinan permainan lainnya juga ditunjukkan dalam DM. pasangan Milly dan Keith harus menghadapi serangan 
Rachel yang terobsesi sebagai wali sang adik, Keith, sepeninggal kedua orangtuanya saat mereka kecil. Rachel dan Keith lalu dititipkan di sebuah panti asuhan. Sejak itu, Rachel bertindak sebagai pengawas bagi Keith. Sikap Rachel yang berlebihan tersebut justru menyiksa Keith, terutama setelah menikah dengan Milly tanpa persetejuan sang kakak. Rachel lalu berusaha membuat maker untuk memisahkan Keith dan Milly. Bahkan, tidak segan sebagai pengelola manajeman artis, Rachel berani melibatkan media untuk membuat isu kedekatan Keith dengan seorang artis agar Milly bersedia melepaskan diri dari kehidupan adiknya. Pada akhirnya, Keith sendiri tidak tahan dan meninggalkan sang kakak dan berkonsentrasi pada usaha yang ia jalani bersama Milly. Cobaan lain, datang dari pihak Milly. Keith rupanya berhasil menaklukan sikap keras sang ibu yang tidak merestui pernikahan mereka. Hal itu disebabkan pengucilan yang dilakukan ibu Milly kepada anaknya karena bercerai dari suami pertama Milly. Perceraian menjadi lahan trauma sang ibu hingga ia tidak menerima setiap hal yang berkaitan dengan kata tersebut.

\subsection{Parenting dalam Hanaco}

Parenting ideal dalam pandangan Risman yang dikemukakan melalui youtube diunduh 18 Oktober 2018 (www.youtube.com/watch?v=Ze4diD9g7LM) dikaitkan dengan tujuh pilar utama dalam pendidikan anak, yaitu (1) orang tua harus sepenuhnya ada untuk anak, (2) dibutuhkan attachment, (3) tujuan pengasuhan jelas (4) atur gaya bicara, (5) pendidikan agama, (6) persiapkan pola pengasuhan saat anak puber, dan (7) ajari anak menahan pandangan. Namun, dalam novel FBH, YHMH, BA, HG, PM, dan CBMSP, idealitas parenting tersebut sulit diterapkan karena lembaga perkawinan sendiri sudah mengalami masalah yang pelik. Hanaco melalui beberapa karyanya tersebut menyampaikan bahwa perkawinan bermasalah tentu akan menyisakan dampak yang tidak sedikit kepada orang-orang di sekitarnya, terutama pada anak-anak. Tindakan pasangan Ferdy-Verna, dalam FBH, berupa penyimpangan seksual lalu menyebabkan anak mereka, Inez, terbentuk sebagai seorang lesbian. Ia mengejar Brisha. Beruntung,

Brisha dapat selamat dari kejaran Inez dengan dukungan kedua orangtua yang digambarkan sebagai pasangan orangtua ideal, serta sahabat dan anggota keluarga lain yang cukup siaga menjaganya. 
Dalam BA, dampak peristiwa terkuaknya jatidiri Lazuardy menyebabkan Mirza dan Avril mengalami depresi yang cukup hebat. Mirza lalu mati bunuh diri karena overdosis. Demikian pula dengan Lazuardy. Meskipun memiliki seorang ibu, Avril tidak dapat mengatasi persoalannya karena sang ibu cenderung membiarkannya dengan cara berdiam diri hingga, akhirnya, Avril terjerat ke dalam dunia prostitusi. Dunia yang sama juga akhirnya mampu menjerumuskan Kimmy dalam CBMSP pascaperceraian kedua orangtuanya. Kimmy yang terbiasa dimanjakan dan bersikukuh untuk menjalani pendidikan seratus persen tanpa memikirkan dunia kerja melakukan maneuver dengan kecepatan yang tidak terduga. Hal itu dilakukan untuk membuang semua dampak buruk perceraian kedua orantuanya. Namun, Kimmy pada akhirnya terjerat dunia prostitusi yang berkait erat dengan profesi sebelumnya, yaitu SPG. Dengan bantuan sahabatnya, Kimmy menjalani dunia yang tidak pernah terlintas di benaknya. Dalam HG, penderitaan Amara dan kakak lelakinya semakin bertambah. Amara terjerat jebakan kawan lelakinya yang kemudian merusak masa depannya. Amara hamil dan beberapa waktu kemudian, ia mengalami keguguran. Akibatnya, Amara menarik diri dari pergaulan di lingkungan sekitarnya, terlebih dengan lawan jenis. Kasus dampak perkawinan yang buruk juga terdapat dalam PM. Ibu Gwen tidak menghentikan aktivitasnya untuk menjadi wanita penghibur, meskipun ia telah menikah dengan resmi dengan suami sahnya yang dulu menjadi salah satu pelanggannya. Hingga perceraian itu terjadi. Perseteruan terjadi antara kakak tiri Gwen terhadap Gwen dan sepasang adik kembarnya yang notabene berbeda dan tidak diketahui siapa ayahnya. Kakak tiri Gwen merasa bahwa dia 'wanita baik-baik' karena terlahir dari keluarga utuh yang lalu rusak karena kehadiran Gwen dan adik-adiknya. Sepeninggal ibunya, kehidupan Gwen tidak membaik. ia terpaksa menjadi tulang punggung bagi adik-adiknya. Dalam kondisi kalut, Gwen terpaksa menitipkan salah satu adiknya di sebuah panti asuhan, yang kelak menjadi sumber traumatis baginya. Pola pendidikan yang berlatarkan lingkungan seks bebas lalu membentuk kakak tiri Gwen, dalam kondisi sebagai anak broken home, terjerumus ke dalam profesi yang sama. Ia mengalami beberapa kali kehamilan dan tidak pernah melepas dendam kepada Gwen dan si kembar yang dianggapnya sebagai penghancur hidupnya. 


\subsection{Masalah dan Penyelesaian Masalah}

Masalah yang muncul dalam karya Hanaco didominasi oleh masalah dalam keluarga dan orang-orang di sekitar tokoh. Masalah yang dialami oleh orang-orang di sekitar tokoh tidak pernah jauh dari latar konflik keluarga. Dalam OB, masalah muncul ketika Sophie tiba-tiba didatangi oleh seorang laki-laki yang bernama Rangga Fahaad. Rangga Fahaad adalah kekasih dari ibu kandung Sophie, Dahniar, saat mereka masih duduk di bangku SMA. Lepasnya pengawasan orang tua, menyebabkan pasangan Dahniar dan Rangga terjerumus ke dalam pergaulan bebas. Dahniar tidak siap dengan dampak pergaulan bebas itu. Dahniar hamil tepat menjelang masa kelulusan. Kehamilannya menyebabkan Dahniar terguncang dan mengalami gangguan jiwa seumur hidupnya. Sementara itu, Rangga tidak pernah mengetahui kehamilan itu. Ikhtiarnya untuk terus berkomunikasi dengan Dahniar ditutup rapat oleh ayah Dahniar. Rangga melanjutkan kuliahnya di Amerika sambil terus berharap kabar dari Dahniar. Ketika batas penantiannya berakhir, Rangga akhirnya menikah dengan wanita setempat. Sementara nasib Dahniar tidak pernah membaik. Hidupnya dihabiskan di rumah sakit jiwa sampai akhir hayatnya. Kematian Dahniar dan kembalinya Rangga dan istrinya itu membuka peluang bagi Sophie untuk merasakan hangatnya keluarga. Perkawinan Rangga yang harmonis menjadi pelabuhan bagi Sophie untuk merasakan parenting yang ideal. Sosok ibu tiri mampu menggantikan kekosongan posisi Dahniar. Kehangatan keluarga mampu mengembalikan kebahagiaan Sophie.

Masalah Amara terjadi karena lepasnya pengawasan orang tua dan ia lengah sehingga terjerat dalam jebakan teman laki-lakinya hingga mengalami kehamilan dan keguguran. Peristiwa kehamilan Amara dan keguguran yang dideritanya semakin memperkeruh situasi perkawinan kedua orang tuanya. Kedua orang tuanya memutuskan untuk bercerai. Sang ibu tidak mampu bertindak sebagai pelindung bagi Amara, tetapi semakin dalam menyiubukkan diri pada aktivitasnya sebagai guru les. Materi kembali menjadi pelarian bagi ibu dan ayah Amara. Luka psikis Amara semakin menjadi dan ia memutuskan untuk menjauhi teman-temannya. Selain itu, ia menutup diri kepada lawan jenisnya. Ia merasa bahwa lingkungan yang ia masuki tidak dapat memberikan rasa aman kepadanya. Ketidakpedulian orang-orang di sekitar Amara menyebabkan peristiwa pemerkosaan yang dialami gadis itu. Trauma perkosaan semakin bertambah ketika Amara mengetahui dirinya hamil, lalu kemudian ia mengalami keguguran. 
Merasa lingkungan sekitar tidak aman, Amara lalu memilih untuk diam dan membiarkan trauma itu hidup bersamanya.

Tapi kesenangannya bergaul mati sejak peristiwa mengerikan itu terjadi. Dia juga berhenti memberikan kepercayaan kepada orang lain, tanpa kecuali. Termasuk kepada orang tua dan kedua kakaknya. (Hanaco, HG, 2015: 18)

Semangat hidup didapatkan Amara secara perlahan dari sahabatnya, Sophie dan Briska. Dukungan semangat dari kedua sahabatnya itulah yang lambat laun mampu membangkitkan kepercayaan diri dan semangat hidup Amara. Satu hal yang menguatkan ketiga sahabat itu adalah masing-masing memiliki kesamaan, pengalaman buruk dengan lawan jenis pada masa lalu. Masalah ketiga sahabat itu lambat laun teratasi karena kesamaan nasib dan kesamaan untuk bertekad memperbaiki nasib, serta menuntaskan masalah mereka. Masalah yang mereka alami juga semakin teratasi ketika masing-masing mendapati pihak yang dianggap sebagai pelabuhan cinta mereka, kekasih sejati.

Dalam LM digambarkan dua kontradiksi antara lepas dan ketatnya etika sosial. Pada satu sisi, ketika seorang perempuan tidak mampu menguasai kesadaran dan emosinya, ia akan melepaskan kemarahannya itu pada hal-hal yang berbau domestik. Sasaran kemarahan dr. Martini dilampiaskan pada Fleur, cucunya sendiri, yang dianggapnya sebagai titik tolak semua permasalahan, terutama kehilangan Renee - anak perempuan kesayangannya. Renee meninggal setelah melahirkan Fleur. Fleur hadir sebagai akibat peristiwa pemerkosaan Renee oleh Noah. Renee dijerat Noah yang sejak awal sudah menandai perempuan itu sebagai mangsa seksualnya. Peristiwa kehamilan Renee mengubah pola pikir dan tabiat dr. Martini. Dr. Martini menjadi kejam dan cenderung keji. Kemarahan yang ia lampiaskan kepada Fleur dapat dikatakan tidak mampu ditahan oleh orang-orang di sekitarnya. Kekerasan fisik dan psikis dialami Fleur setiap saat. Siksaan bagi Fleur bukan hanya bersumber dari neneknya saja, melainkan didapatkannya dari kaum laki-laki yang ada di sekitar Fleur. Paman, tukang kebun, dan sopir pribadi dr. Martini juga melakukan kekerasan seksual kepada Fleur sehingga memecahkan kepribadian Fleur pada banyak pecahan. Selain itu, serangkaian penyiksaan tersebut menyebabkan sakit kepala berkepanjangan dan kehilangan daya ingat pada diri Fleur. Jika demikian, pada momen tertentu, Fleur dapat berubah menjadi binal atau keji, misalnya membunuh dr. Martini, atau berpose erotis di sebuah tempat penginapan.Pada saat Fleur berubah sebagai "Fleur" yang lain, lingkungan setempat 
seakan tidak dapat berbuat apa-apa. Fleur mampu meredakan dirinya menjadi Fleur sejati ketika ia berada bersama Erick, kekasih hatinya. Namun, jika Erick tidak ada dan gadis itu bertemu dengan orang yang pernah menyakitinya, ia akan menjelma menjadi Fleur lain yang memiliki perangai cenderung keji. Hanaco memberikan gambaran bahwa anak yang sejak kecil membawa luka batinnya akan sulit disembuhkan.

Masalah yang muncul dalam novel-novel Hanaco berkaitan dengan parenting yang keliru. Sosok Andaru dalam FBH, mantan kekasih Brisha, terlahir dalam situasi keluarga yang memberikan kebebasan secara tanpa batas, tanpa dikenalkan dengan kata tidak. Kelak, ketika tumbuh besar, Andaru tidak pernah terdidik untuk mengatasi masalah secara sistematis. Ia mengatasi masalah dengan emosi yang tidak terkendali dan cenderung mengarah pada kriminalitas. Terjerumusnya Avril dan Kimmy ke dalam dunia prostitusi semata dipicu oleh kekecewaan yang tinggi terhadap sosok orangtua, terutama ayah. Kekecewaan pada sosok ayah yang selama ini sangat disanjung dalam sekejap membelokkan pendirian kedua gadis itu semata untuk menunjukkan balas dendam terhadap sosok ayah. Masalah dalam Hanaco muncul dan berkembang karena terdapat unsure pembiaran. Sikap tokoh Mama dalam BA tidak menunjukkan aksi cepat tanggap, baik terhadap penyelesaian masalahnya sendiri maupun anak perempuannya. Ia lebih memikirkan pada kepentingan ekonomis dengan menjadi pengawan sektor keuangan di perusahaan milik suaminya. Perceraian yang terjadi antara orangtua Amara (HG) dan Kimmy (CBMSP) terjadi karena dibiarkan dan tidak saling ingin mengatasi persoalan sejak dini. Yang muncul adalah sikap membiarkan masalah menjadi berlarutlarut, hingga mencapai puncak perpecahan, serta diperburuk dengan bermunculannya masalah susulan. Penyelesaian masalah yang ideal bagi masyarakat modern adalah penyelesaian bergaya instan, dengan gaya militan-misalnya, tanpa harus belajar mengendalikan emosi dan mengembangkan kesabaran. Penyelesaian masalah yang demikian kini menjadi budaya massa dan dengan mudah diketahui oleh khalayak ramai, bahkan di seantero dunia. Media massa, terutama elektronik, dengan fitur yang mudah diakses dan dijalankan semakin memuluskan penyebaran konsep solusi instan tersebut. Pada sisi yang lain, Hanaco selalu menawarkan bahwa untuk hidup tangguh di dunia yang sarat budaya massa dan peliknya lingkungan urban, mereka harus dibekali dengan sarana dan prasarana yang kokoh. Prasarana yang ditawarkan oleh Hanaco adalah keluarga ideal. FBH menampilkan figur keluarga ideal yang dimiliki oleh tokoh Brisha. 
Keluarga ideal memiliki kemampuan aksi cepat tanggap yang cukup baik. Hal itu terjadi ketika tokoh Brisha mengalami kekerasan fisik dari mantan kekasihnya, Andaru, dan tetangga yang seorang lesbian, Inez. Sementara itu, tokoh Gwen dalam PM mendapat dukungan penuh dari suaminya, dan sahabat suaminya ketika ia mendapatkan gangguan berkepanjangan dari kakak tirinya sendiri. Terkadang, gaya penanggapan seseorang terhadap masalah tidak saksama, sebaliknya emosi meledak dengan cepat dan tidak terkendali. Hal itu terjadi pada novel YHMH, ketika tokoh Navid memaksakan kehendaknya untuk menikahkan anak sulungnya dengan Alistair, anak dari kenalannya - pasangan Damanik. Ketika, Ina-Alistair mengalami masalah, dan melihat Ina kembali ke rumah, Navid memandangnya dengan cara emosional. Ia hampir menutup jalan bagi Alistair untuk menemui istrinya. Dalam $\mathrm{MH}$, tokoh Audra bersikap resisten pada lawan jenis karena ia pernah mengalami trauma perceraian orangtua. Ibu kandung Audra bersikukuh enggan diceraikan, sementara ayahnya bersikap sebaliknya. Pascaperceraian tersebut, kondisi ibu kandung Audra merosot tajam hingga harus menghabiskan hidupnya di tempat rehabilitasi jiwa.

\footnotetext{
"Cinta yang luar biasa besar pada mantan suaminya membuat perempuan itu tersiksa. Martika yang sejak awal enggan bercerai, bergelut dengan kesedihan selama bertahun-tahun. Itulah salah satu yang mendorong Audra untuk meninggalkan tanah kelahirannya. Dia tidak tahan melihat ibunya menderita karena cinta. Sementara di sisi lain, ayahnya justru terlihat lebih bahagia karena perpisahan mereka.

Apa yang terjadi pada orangtuanya membuat Audra takut jatuh cinta. Apalagi dia punya pengalaman buruk dengan Jiro. Semua itu menjadikan gadis itu sangat berhati-hati untuk urusan cinta. Tapi, kemudian dia bertemu Val. Audra sudah cukup lama menahan diri, menyembunyikan perasaan sesungguhnya kepada cowok itu. Entah sampai berapa lama. (Hanaco, MH, 2017: 325)
}

Kekasihnya, Val, berasal dari latar keluarga utuh tetap sama halnya dengan Keith, ia mengalami tekanan overprotektif dari kakak kandungnya. Tidak mengherankan jika keduanya saling memperkuat resistensi hingga akhirnya mencapai titik temu. Sementara itu, kasus penyelesaian bias gender juga dapat dikatakan mendominasi novel-novel Hanaco. Hanaco masih menempatkan tokoh perempuan, seperti yang dikatakan oleh Ibrahim (1997: 20) sebagai dekor. Ia layak dipandang dan mampu mengundang emosi pembaca karena ia mengusung beban masalah yang luar biasa. Kepasifan juga banyak ditonjolkan karena tokoh perempuan cenderung untuk membiarkan masalah sepele, seperti yang dialami Ina-Alistair dalam YHMH, menjadi masalah yang besar hingga merenggangkan hubungan dua keluarga atau pihak-pihak di sekitar lingkungannya. Indah selalu menghadirkan sosok pahlawan yang notabene kaum laki-laki sebagai pihak 
yang dapat memulihkan persoalan seseorang (perempuan). Namun, pahlawan yang ditampilkan pun bukanlah pahlawan yang sempurna, tetapi sama-sama mengusung latar traumatis yang berujung pada pengalaman parenting yang buruk. Pada akhirnya, Hanaco selalu mengembalikan konflik-konflik manusia modern pada konsep penyelesaian masalah secara tradisional, seperti pernikahan yang ideal atau kembali pada konsep keluarga bahagia/ideal dengan formasi lengkap, yaitu ayah-ibu harmonis, atau ayah/ibu dan sosok pengganti ayah/ibu yang mampu menerima si korban dengan apa adanya.

Masalah dalam potret keluarga urban tadi terjadi karena adanya lingkungan masyarakat urban yang cenderung mengabaikan jaringan kepedulian pada sesama. Pada novel LM, tokoh dr. Martini cenderung bebas melakukan eksekusi kepada Fleur karena lingkungan di sekitarnya cenderung membiarkan hal itu. Pelayan, sopir, atau kerabat tidak mampu berbuat apa-apa ketika Fleur dicelakai oleh neneknya sendiri. Sebaliknya, lingkungan sekitar Fleur cenderung memberikan dukungan yang negatif kepada korban. Salah seorang anggota keluarga dan beberapa tokoh laki-laki yang ada dalam kehidupan Fleur melakukan perbuatan tercela yang pada akhirnya semakin membuat gadis itu "sakit". Penyebab munculnya masalah lain, adalah mudahnya publik masuk dalam ranah privasi. Perkawinan seperti permainan puzzle yang dapat dimainkan oleh siapa saja. Akibatnya, perkawinan mudah rapuh dengan banyaknya kepentingan di dalam ranah privasi. Problem solving dalam novel Hanaco kerapkali berujung kekerasan, baik fisik maupun psikis. Hal itu merupakan cerminan bahwa moral dan nurani sudah mulai tercabut dari manusia urban. Penyelesaian masalah cenderung dilakukan dengan cara yang "mudah" tetapi tanpa penuh pertimbangan yang matang. Tidak mengherankan jika solusi yang dipilih sang tokoh di kemudian hari menimbulkan sederet masalah baru.

\subsection{Hubungan Antarsesama}

Hubungan antarmanusia di tengah wilayah urban, merupakan hubungan dalam lingkungan yang terkotak-kotakkan. Pertemanan cenderung sempit dan hanya dengan orang yang dianggap memiliki kesepahaman. Hubungan Fleur dan neneknya sendiri, dalam LM, merupakan hubungan antara mangsa dan pemangsa. Dr. Martini tidak pernah menerima kehadiran Fleur murni sebagai cucunya sendiri. Fleur ditempatkannya sebagai titik pelampiasan kemarahan dan kesedihannya atas kehilangan anak perempuan satu-satunya, ibu Fleur.Kekerasan itu dilakukannya secara kontinyu yang pada akhirnya 
merusak kepribadian Fleur. Sementara itu, kehidupan para pemuja seks bebas dalam novel CBMSP dan BA terjadi di sebuah tempat yang menyajikan privatisasi kelas tinggi dengan keamanan akses yang cukup ketat. Selain itu, hubungan antarmanusia juga menjadi santapan komoditas yang menyajikan kebahagiaan yang semu dan penuh ilusi. Tokoh Gitta harus menempuh risiko tinggi ketika ia menyimpang dari profesinya sebagai fashion stylish seorang artis - yang notabene telah lama terjerumus dalam dunia prostitusi. Gitta melakukan semuanya dengan latar-kembali pada permasalahan akarakibat pergaulan bebas, kehamilan di luar nikah, dan perkawinan yang menemui kegagalan. Gitta harus rela meninggalkan anaknya di Pulau Kalimantan demi melampiaskan dendam dan kekecewaan, serta demi meraih kepuasan akan kebutuhan materi. Ia harus menanggung risiko kerusakan fisik dan trauma atas perlakuan kasar dan kekerasan seksual dari salah seorang pelanggannya. Namun, peristiwa buruk tersebut tidak membuat Gitta untuk keluar dari dunia tersebut, seperti yang ia utarakan pada Sophie berikut.

Gitta mengusap pipinya. "Sebelum ini, aku nggak pernah jadi korban kekerasan atau hal-hal semacam itu. Semua baik-baik saja, sampai kemarin itu. Memang, kerjaan ini berisiko. Tapi sepadan sama... materinya." (Hanaco, OB, 2015: 249)

"Aku kan sudah bilang, Sophie, aku bodoh. Aku nggak pernah mengira akan bisa sampai kayak gini. Bukannya sok alim, tapi kerasa... aku sudah terlanjur nyaman kayak gini. Tapi... Dicky dan aku mungkin akan lebih... ekslusif.” (Hanaco, OB, 2015: 251)

Kutipan Gitta tersebut menunjukkan bahwa Gitta lebih memilih untuk menempuh risiko berat demi kepuasan materi yang ia dapatkan. Selain itu, Gitta merasa bahwa ia sudah terlanjur bernoda dan tidak mungkin hidup di ranah umum. Terkadang hubungan antarmanusia di dunia modern tersebut dikonstruksi melalui media komersial. MH menawarkan konsep perjodohan dalam sebuah tayangan yang pernah menjadi tren di dunia infotainmen-Take Me Out. Dalam novel acara tersebut disebut Meet the Millionaire. Tokoh Audra terpaksa mengikuti acara tersebut setelah tidak dapat menahan paksaan teman-temannya. Namun, Audra memutuskan untuk mengundurkan diri karena tidak tahan dengan kesemuan yang muncul selama masa karantina. Audra ingin kembali ke dunia realitas yang membawanya kembali pada dunia kampus dan teman-teman kosnya. Sementara itu, Val berhasil memenangkan program tersebut meskipun memutuskan untuk tidak melanjutkan hubungan dengan partner dalam program tersebut. Baik Val maupun Audra, tidak dapat menerima konsep cinta yang 
dikonstruksi oleh dark power yang mengendalikan acara tersebut, dan memilih untuk menjadi manusia dan menjalani kehidupan cinta apa adanya.

\section{PENUTUP}

Urban menawarkan segala kompleksitas, termasuk gaya hidup. Manusia cenderung untuk terjerumus dan terbius ke dalam kebahagiaan semu dan penuh ilusi, yang ditawarkan nilai-nilai baru yang dianggap lebih mudah. Hal itu tampak dalam beberapa novel karya Indah Hanaco. Tokoh dalam novel Hanaco digambarkan sebagai manusia yang dilahirkan dan hidup dalam lingkungan urban yang kompleks. Dalam perkawinan, sosok ayah-ibu berkembang menjadi sosok asing yang saling melemparkan nilai yang berseberangan. Akibatnya, anak keturunan mereka menderita secara lahir maupun batin. Pagar privasi dalam perkawinan cenderung longgar sehingga setiap orang dapat dengan mudah menyelinap ke dalam ranah privasi itu. Konsep parenting sulit dijalankan dengan baik, sehingga tidak menutup kemungkinan anak-anak mereka akan tumbuh menjadi pribadi lemah atau cenderung brutal. Rentang jarak anak dan orang tua cenderung jauh. Akibatnya timbul banyak masalah, antara lain dalam wujud kriminalitas dan penyimpangan seksual. Keberhasilan penyelesaian masalah dalam parenting maupun perkawinan dalam Hanaco ditunjukan dengan kehadiran sosok yang benar-benar mampu menjadi pahlawan sejati, antara lain keluarga ideal, sahabat, atau kekasih. Sementara itu, hubungan antarsesama lebih dikaitkan pada kepentingan pribadi atau kepentingan yang sama. Di luar itu, manusia urban cenderung untuk sulit bernegosiasi dan berdamai.

\section{DAFTAR PUSTAKA}

Damono, Sapardi Djoko. (1997). "Kebudayaan Massa dalam Kebudayaan Indonesia: Sebuah Catatan Kecil" dalam Ibrahim, Iding Subandy. 1997. Ecstasy Gaya Hidup: Kebudayaan Pop dalam Masyarakat Kebudayaan Indonesia. Hlm 4751. Bandung: Mizan.

Hanaco, Indah. (2011). Black Angel. Yogyakarta: Stiletto Book.

Hanaco, Indah. (2012). The Curse of Beauty: Metrolifestyle Sales Promotion Girl. Malang: rumah Kreasi.

Hanaco, Indah. (2014). Les Masques. Jakarta: Jakarta: Grasindo..

Hanaco, Indah.(2014). My Better Half. Jakarta: Elex Media Komputindo.

Hanaco, Indah. (2015). You Had Me at "Hello". Jakarta: Elex Media Komputindo.

Hanaco, Indah. (2015). Heartling. Jakarta: Gramedia Pustaka Utama.

Hanaco, Indah. (2015). Out of the Blue. Jakarta: Gramedia Pustaka Utama.

Hanaco, Indah. (2016). Delicious Married. Jakarta: Grasindo. 
Hanaco, Indah. (2017).The Passionate Married. Jakarta: Grasindo.

Hanaco, Indah. (2017). Fixing A Broken Heart. Jakarta: Gramedia Pustaka Utama.

Hanaco, Indah. (2017). Millionaire's Heart. Jakarta: Moka Media.

Ibrahim, Iding Subandy. (1997). Ecstasy Gaya Hidup: Kebudayaan Pop dalam Masyarakat Kebudayaan Indonesia. Hlm 12-43. Bandung: Mizan.

Jabrohim. (2010). "Membaca Budaya Urban di Yogya, di Mana Posisi Sastra" dalam Setijowati, Adi, et.al. 2010. Sastra dan Budaya Urban dalam Kajian Lintas Media. Prosiding Konferensi Internasional Kesusastraan XXI HISKI kerjasama HISKI PUSAT dan Universitas Airlangga. Surabaya: Airlangga University Press.

Maranoes, Ariel. (2007). "Potret Kaum Buruh Urban" dalam www.liputan6.com/amp149421/potret-kaum-buruh-urban diunduh 26 November 2017, pukul 09.06 WIB.

Marbun, Thomas. (2016). "Menuju Pernikahan Ideal: Memahami Masalah dan Mencari Solusi” dalam www.kompasiana.com diunduh 21 November 2018.

Mustikasari, Dinda. (2018). "Perilaku Ganggung Identitas Dissosiatif (GID) Tokoh Fleur Radella dalam Novel Les Masques Karya Indah Hanaco: Sebuah Pendekatan Struktural dan Psikoanalisis". Skripsi. Yogyakarta: Prodi Sastra Indonesia Fakultas Sastra Universitas Sanata Dharma.

Nurfaidah, Resti. (2016). "Dampak Disfungsi Keluarga terhadap Mitos dan Kecantikan dalam Novel The Curse of Beauty: Metrolifestyle Sales Promotion Girl" dalam Widyastuti, Thera, dkk. (2016) Prosiding Seminar Nasional Kesusastraan Indonesia Mutakhir, Depok: FIB UI, hlm. 1-15.

Purwantini. (2010). "Masyarakat Urban, Budaya Urban, dan Sastra Urban di Indonesia: Kajian Lintas Media" dalam Setijowati, Adi, et.al. 2010. Sastra dan Budaya Urban dalam Kajian Lintas Media. Prosiding Konferensi Internasional Kesusastraan XXI HISKI kerjasama HISKI PUSAT dan Universitas Airlangga. Surabaya: Airlangga University Press.

Risman, Elly. (2016). "Dampak Sekolahkan Anak Teralu Dini” dalam Indonesia Morning Show Net TV dalam https://www.youtube.com/watch?v=Ze4diD9g7LM diunduh 18 Oktober 2018.

Soerjono, Soekanto. (2002). Sosiologi: Sebuah Pengantar. Rajawali Press: Jakarta.

Suwardi. (2010). "Membaca Gaya Hidup Life of Stage dan the Aneh Lewat Sastra Lisan Jawa" dalam http://staffnew.uny.ac.id/upload/131872518/penelitian/ hiskisurabayapdf.pdf diunduh 29 Mei 2018.

Takwin, Bagus. (2006)."Kota dan Kita” dalam Resistensi Gaya Hidup: Teori dan Realitas. Yogyakarta: Jalasutra. 